\title{
Communication Strategy for New Public Transport System (Case Study: PT Mass Rapid Transit (MRT) Jakarta Communication Strategy)
}

\section{Mareta Maulidiyanti}

Vocational Communication, Vocational Program, Universitas Indonesia

\section{Abstract}

This research discusses communication strategy role in the process of building a positive image and public trust toward the new public transportation system in Jakarta, Mass Rapid Transit (MRT) Jakarta. This article examined how communication strategy plays a strategical role during significant project phase. According to the experience, differentiated communication tactics during different phases of project

Corresponding Author: Mareta Maulidiyanti

Received: 8 June 2018 Accepted: 17 July 2018 Published: 8 August 2018

Publishing services provided by Knowledge $\mathrm{E}$

(c) Mareta Maulidiyanti. This article is distributed under the terms of the Creative Commons Attribution License, which permits unrestricted use and redistribution provided that the original author and source are credited.

Selection and Peer-review under the responsibility of the 2 nd ICVHE Conference Committee. can have an important role on public level of acceptance. Communication strategy is very important because the MRT Jakarta is the first MRT system in Indonesia. It is carried out by the government companies that are called PT MRT Jakarta. It is fully funded by the government through Japanese loans. As a Public Project using the state budget, MRT has always been in a public spotlight and vulnerable to be a hot issue. Moreover, people are required to be patient waiting for the MRT through the construction phase that would always bring the impact and changes for the community (traffic jam along the corridor, land acquisition, etc.). From the service, MRT Jakarta is also expected to be able to encourage people shift from private vehicles to public transport. To achieve this, the company needs a comprehensive communication strategy since the preconstruction \& construction phase until the operation period. So this research is attempting to explore MRT Jakarta Company communication strategy to achieve those goals. Through qualitative descriptive method, research aims to find if the Corporate Communication Division implements the effective strategy based on the theory or not. This method systematically describes the communication strategy formulated by MRT Jakarta Company. The research used interview method to collect the data. From this research, we know that PT MRT Jakarta builds key messages, chooses the campaign program, chooses the media tools and how the PR measures for the success of the program.

Keywords: public relations, communication strategy, Mass Rapid Transit (MRT), transportation, descriptive 


\section{Introduction}

Public relations is a strategic communication process that builds mutually beneficial relationships between organizations and their publics (PRSA, 2011). It means Public Relations is a management function that is responsible for building good relations with the public.

In communication, public perception is the key to create an effective, efficient $\&$ mutual understanding communication. Effective means the results meet/match the expectation. Efficient means achieving goals with the minimal cost, time and personnel. The Newcomb' ABX Model explained that a communication process will run smoothly if both parties have the same understanding of an object. If the understanding is not the same or the opposite, then the communication links between two sides will not be harmonious and effective ([2], p. 248).
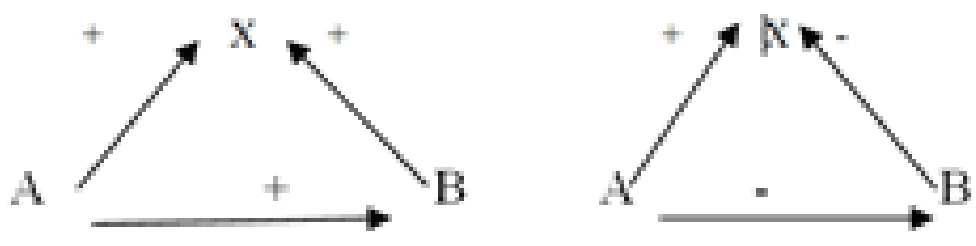

Figure 1: ABX Newcomb model.

In this model, A and B are considered as two different parties and both have an understanding of an object that is called $X$. If $A$ and $B$ have the same view on $X$ then the communication link between $A$ and $B$ will be positive. Otherwise, if $A$ and $B$ have $a$ different view on $X$, then the relationship $A$ and $B$ will be negative. Differences not only about opinion and dissent but also can be caused by differences information owned by $A$ and $B$. For example, A got more information than $B$, then it will make their views on $X$ will be different. Therefore, it can be concluded that the PR activities within the organization aims to build public understanding of the organization and create a good relationship between the organization and its publics so that relationship can be established and maintained a positive image of the organization ([7], pp. 44-45).

This study will focus on the communication strategy of PT Mass Rapid Transit (MRT) Jakarta. This company is owned by DKI Jakarta Provincial Government that responsible for building and operating the MRT Jakarta System in Jakarta. The heavy rail-based MRT Jakarta will span $\pm 110.8 \mathrm{~km}$, consisting of the South-North Corridor (Lebak Bulus - Kota Area) of about $23,8 \mathrm{~km}$ and the East-West Corridor of about $87 \mathrm{~km}$. The Construction 
of south-north corridor that stretches along Lebak Bulus - Kota Area will be carried out in 2 stages: (PT MRT Jakarta, 2016).

1. Stage 1 will be carried out to connect Lebak Bulus with Bundaran HI over $15.7 \mathrm{~km}$ railway with 13 stations (7 elevated stations and 6 underground stations) which is targeted to operate by 2018.

2. Stage 2 will expand the South-North Corridor from Bundaran HI to Kota Area over $8.1 \mathrm{~km}$ railway, which will be constructed before Stage 1 operates and is targeted to be completed on 2020. Feasibility study for this stage has been completed.

Today, MRT Jakarta is on progress to finish their $1^{\text {st }}$ stages. As the public project that fully funded by Japanese Loan, makes MRT Jakarta always be in the spotlight. Everything they do is watched by the Government, NGO, Media and also Jakarta's Citizen. People asked them about transparency and waiting for their progress. During this construction period, public faced by the traffic jam issue, land acquisition and spectism about the project success. Besides that, MRT Jakarta is expected to be able to encourage people shift from private vehicle to public transportation and ensure that MRT Jakarta will be able to serve people with comfortable and reliable service.

This situation showed that people need a lot of information about the project from what MRT is, why we need MRT, scope of its services, its construction progress, the compensation of public land and so on. It means, the company needs a comprehensive communication strategy to educate and gain people trust and mutual understanding. Furthermore, this trust and mutual understanding can drive a positive image for the company and its service.

So, the purpose of this study is to see How PT MRT Jakarta communication strategy shape the positive image.

\section{Literature Review}

\subsection{Effective communication}

Communication is a process of changing people behavior to affect attitudes, opinions and behavior when the communication is done communicatively (Holand, in [4]: 10). Communication is successful and effective when messages were successfully received by the message recipient ([4]: 11). Water Lippman in Effendy (2005: 11) said that effective communication is the communication that is trying to choose the right way to make communicator's idea/messages can be understood by the communicant. 


\subsection{Communication element}

Lasswell's Communication element described through communication model:

\section{Lasswell's Communication Model}
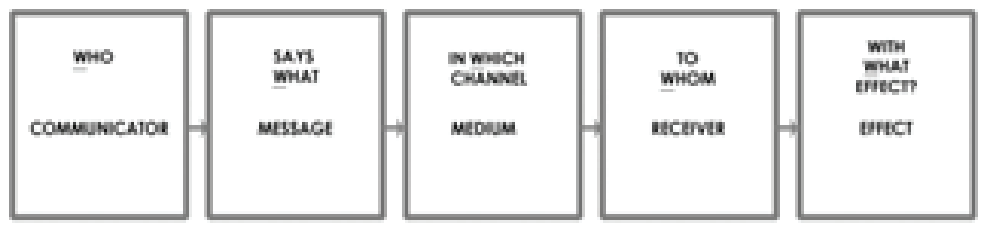

Figure 2: Lasswell's communication model.

According to Gamble (2002), Communication models depicted in a circle of communication where the message is the responsibility of the communicator. The message can be delivered through one or more medium. In contrast with Laswell, Gamble adds noise components in communications. Noise can come in the process of interaction and influence communicators and communicant in delivering and receiving messages. In essence, communication is what to say, words are used, voice, gestures and expressions are performed in the communication process.

\subsection{Public relations \& communication strategy}

Jefkins (2003) states that Public Relations (PR) always related with the effort in creating public understanding through knowledge. PR is a form of communication that is applicable to all types of organizations in both the commercial and non-commercial, public sector (government) and private sector. Jefkins (2003) stated that PR is defined as the communication effort that is planned and sustainable in order to create, maintaining a goodwill and mutual understanding between an organization and its public.

Belch \& Belch (2012) said that public relations is a management function which evaluates public attitudes, identifies the company's policy against the public interest and implement a communications program to gain public understanding and acceptance. Effective PR activities can only be achieved when implemented consistently and continuously.

Communication Strategy is essentially a combination of a communication plan and communication management to achieve goals (Effendy.2003. p. 301). Communication program should answer this question: "Who Says What in What Channel To Whom With What Effect?" 
The communication strategy will contribute to the overall corporate strategy, the communication strategy should refer to the company's strategy (Hoffjann, Juliana, 2012). However, the contribution of communication management to company's strategy is depend on the type of company [13]. Botan (2006) called a company strategy with 'Grand Strategy' which is a strategy in policy level while the 'Strategy' is positioned at the level of execution/policy campaign.

Journal of Corporate Communication and Strategy in the Field of Projects [14] said that in a project communication, Corporate Communication execute communications strategy with specific objectives. The important thing is to build trust by reducing the asymmetry information with the public. The communication strategy should be designed differently based on the public (Internal \& External public). Furthermore it was said that in a project, communication strategy need to adjust based on the project phase.

\subsection{Image}

Frank Jefkins (2003:412) interpret the image as an impression (according to the actual reality) regarding personnel policies, products or services of the organization or company

Rhenald Kasali (2003:30) Defining image as the impression comes from understanding the reality. The understanding exists because of the information.

\section{Methodology}

This research is a descriptive research. Descriptive research is a research method where the variable indicator is the answers to the verbal or written questions (Michael H. Walizer, 1993, p. 225). According to Neuman (2003), descriptive research give the complete picture about the situation, social phenomenon and a relationship. This method makes it possible to examine only one variable or more ([11], hal.12).

This research design is qualitative which implement based on natural condition to collect data from informant without any interversion ([8], p. 4). The result of this qualitative research may be applied to the similar situations and circumstances ([9], p. 29).This research use case study strategy. The qualitative research with case study strategy. Case study needs an intensive research, use some data sources and limited by time and research location. The case could be an organization, group of people, 
community, phenomenon, process, issues and campaign program (Irawan, 2006, p. 13).

The primary data collection were conducted in qualitative approach, which involved interview methods with PT MRT Jakarta Corporate Communication team. Whereas, the interview scope is all about how the Corporate Communication Bureau in PT MRT Jakarta make a planning, implementation and evaluation of their communication program. This interview also identified what kind of communication activities/campaign that held to gain public support.

Data Analysis - A qualitative content analysis was chosen to analyze many words of texts, which are transcribed from interview discussions. Content analysis is a technique for compressing large amounts of data from the interviews, field notes, and various types of sources into systematic and fewer categories of text which is based on specific rules of coding (Steve, 2001). Many previous studies have shown that content analysis can be a useful method for allowing researcher to discover and describe the focus of individual, group, institutional, or social attention (Weber, 1990). In this study, the crucial process in content analysis is categorizing some key words from the given texts into certain themes.

\section{Results \& Discussion}

PT MRT Jakarta has been trying to communicate with their public since 2009. At that time, the project was in feasibility study phase. Communications program starts from determining the corporate identity, building awareness, interest, public education to create a positive behavior until the issue \& crisis management. Their communication roadmap shows in the following figure:

From this roadmap, we can see that the company set the communication goals based on the project phase.

In 2010, when the project was still in the feasibility study, the communication strategy is set up to build the public awareness. At that time, the company implemented many programs to educate public about what MRT is, who PT MRT Jakarta is, where the first line will be build, why Jakarta need MRT, what will be happened in construction period (impact) and ask the public support to the project. Those issue became the key messages in every PR activities because at that time, "the was no people aware about MRT." The Company focused on media relations, online media and public road show, experiential program to educate the publics. 


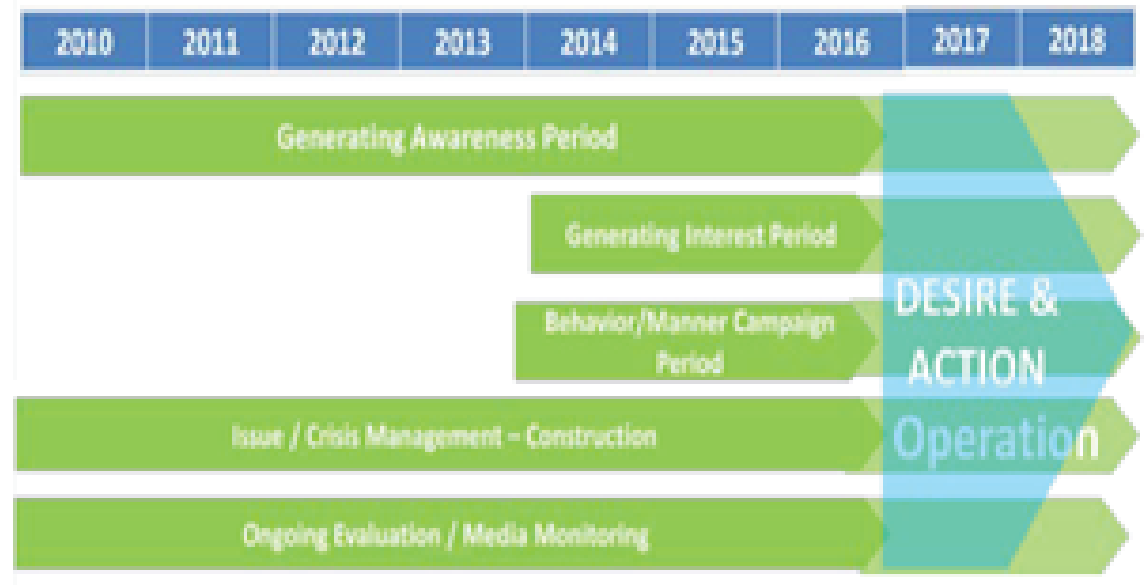

Figure 3: PT MRT Jakarta communication roadmap. Source: Communication Plan PT MRT Jakarta.

After all the program between 2010 - 2013 there was a quantitative research that involved 200 respondent's along the MRT Corridor. The research found that people already know and aware with the MRT. People said they will support MRT Jakarta project if the company give a comprehensive information, transparent, immediately implement and give the affordable price for the passengers.

Those research also showed that public hope that the MRT construction and operation will be implement as soon as possible. They also hoped that MRT can be a solution for Jakarta traffic jam problem.

Today, the project is entering the construction phase. This phase required a commitment from the management to build a good communication with the public. Corporate Communication Bureau has a strategic position under the Corporate Secretary. Corporate Communication has a direct access to board of director and guide them about the communication strategy.

The corporate communication run some PR function such as:

\section{- Media Relations}

Regular press release about the progress or issues, press conference, maintaining journalist databased, media visit to foreign country that has an MRT system.

\section{- Event Management \& Visitor Center}

This function manage some exhibition, seminar, and the visitor center construction. The visitor center will be develop as an information center about MRT. It will 


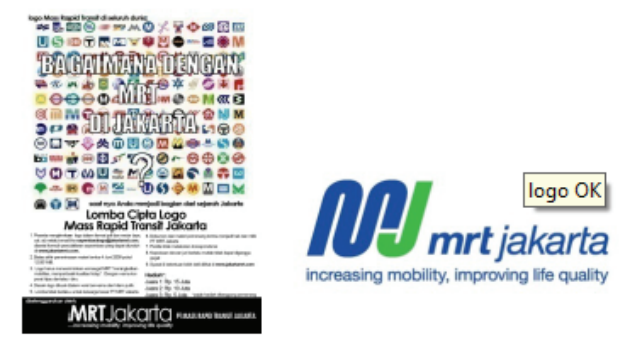

\section{Logo Competition}

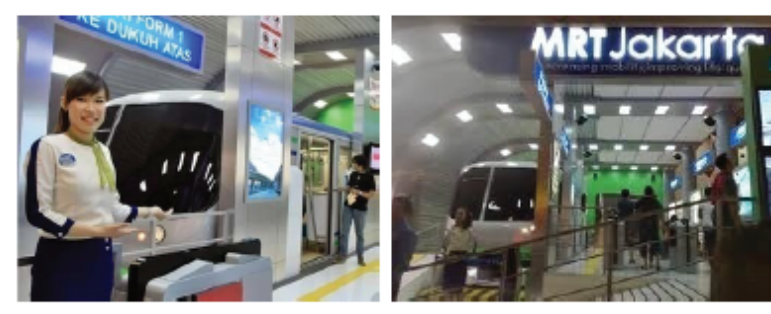

\section{Mock Up Exhibition}
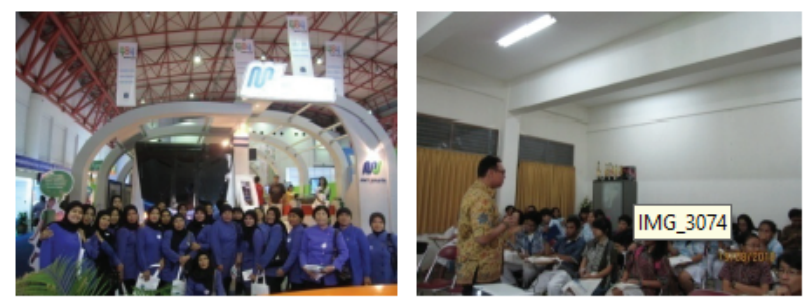

Figure 4: PKK \& High School Road Show, PT MRT Jakarta Program. Source: PT MRT Jakarta.

provide some education material (brochure, video) and there will be a customer service people to provide the information that people needs.

\section{- Social Media \& Website Management}

PT MRT Jakarta has its official website (www.jakartamrt.co.id). It contained a company information and the construction progress report. Besides that, PT MRT Jakarta also maintained their follower in social media such as twitter, Facebook and Instagram. In those platform, the company can make an interactive/two way communication with its public. Through the social media, the company can share the information more often and in a casual way (sharing pictures, event live report and so on)

\section{- Reporting and Internal Communication}




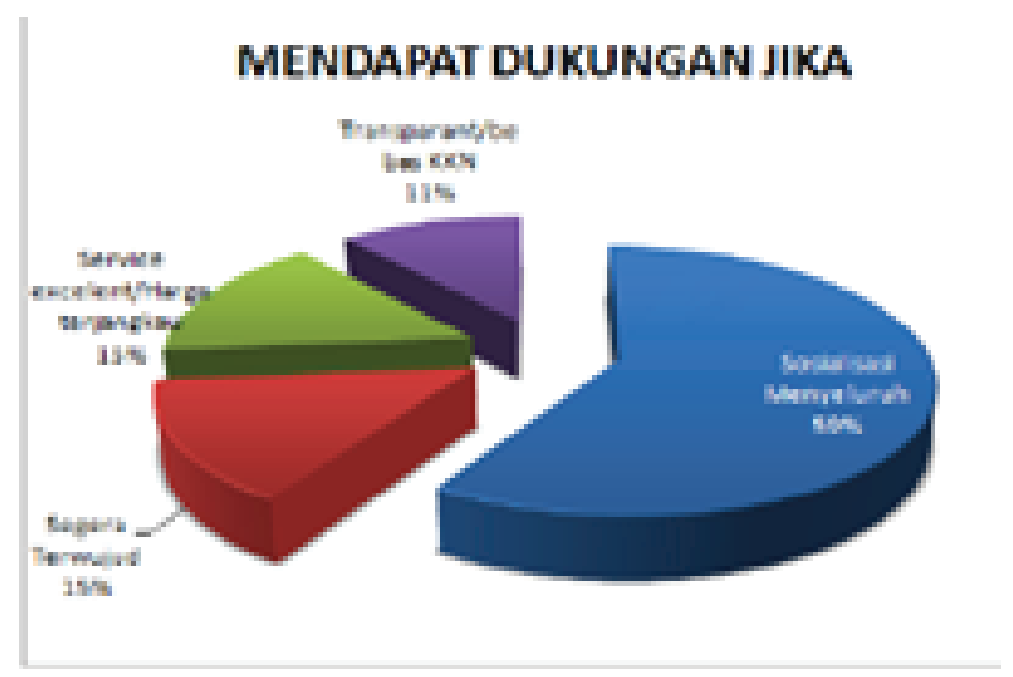

Figure 5: Requirement to support MRT.

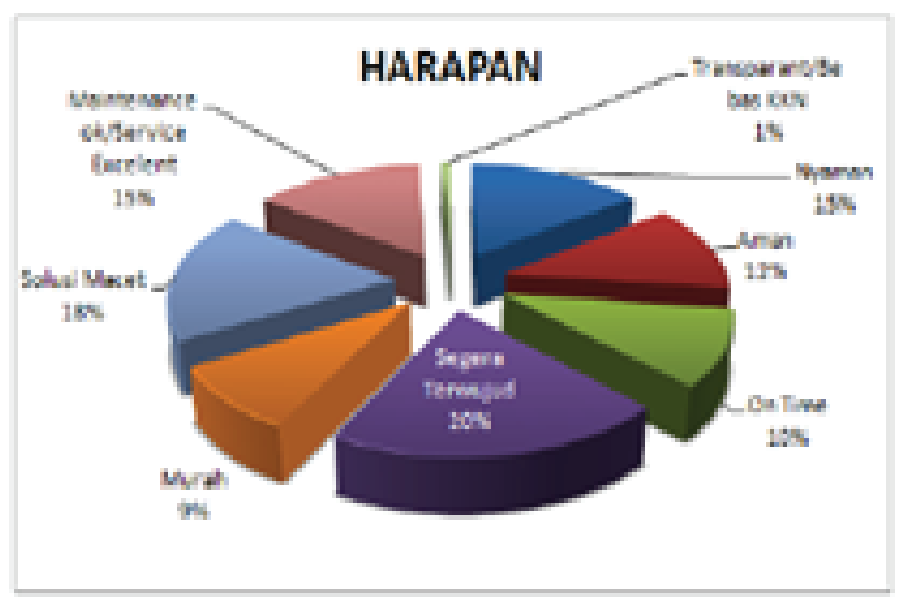

Figure 6: People hope about MRT.

PT MRT Jakarta is owned by DKI Jakarta Provincial Government and it is fully funded by Japanese Loan which also involves central government. It means, the company responsible for reporting to the government. Report \& presentation preparation is under this reporting and internal communication function. In the next few years, this function will also handle employee engagement program.

Onong Unchjana Effendy (1999) describe that PR work process is consist of situation analysis, implementation and evaluation. Corporate Communication in PT MRT Jakarta have already done those process. They do the situation analysis through daily media monitoring and public awareness survey. Then, they also has an annual communication plan as a planning process. This communication plan consist of target audiences, communication purposes, key messages and all programs that will be execute in that year (including budget and target of implementation time). Then, Before they implement 
the program, there will be a term of reference that contained the program detailed (from background, purpose, budget, evaluation). At the end of the year, they will make an evaluation program that measure if the communication program is success or not.

There are some indicators in evaluation process:

1. The number of programs that have been run

2. Public Awareness Index. To get this result, the company hired an external public relations consultant (expert). This expert will make an annual survey about public awareness index. The surveys conducted in various different area in Jakarta especially around the MRT corridor. So, from this survey, we can know which area that has a high/low public awareness index.

TABLE 1

\begin{tabular}{|c|c|c|c|}
\hline Phase & Strategy & Key Messages & Communication Activities \\
\hline Рга - Construction & $\begin{array}{l}\text { Building } \\
\text { Awareness about } \\
\text { MRT }\end{array}$ & $\begin{array}{l}\text { Why we need } \\
\text { MRT, Project } \\
\text { Features, Benefit } \\
\text { we gain by using } \\
\text { MRT, Project } \\
\text { Progress }\end{array}$ & $\begin{array}{l}\text { PR: Road Show (Exhibition, Visit to } \\
\text { Project Affected People, and so on), } \\
\text { Media Relations, Endorser, } \\
\text { Experiential Marketing,:MRT Replica } \\
\text { Online Media }\end{array}$ \\
\hline $\begin{array}{l}\text { Construction } \\
\text { Phase }\end{array}$ & $\begin{array}{l}\text { Build an Interest } \\
\text { and Positive } \\
\text { Behavior }\end{array}$ & $\begin{array}{l}\text { MRT Technology, } \\
\text { Construction } \\
\text { Update, MRT \& } \\
\text { Urban Lifestyle }\end{array}$ & $\begin{array}{l}\text { PR: Mall Roadshow, Office Road Show } \\
\text { Advertising: Advertorial, Project Signage } \\
\text { Online Media Experiential Marketing: } \\
\text { Project Visit }\end{array}$ \\
\hline Operation Phase & $\begin{array}{l}\text { Build Desire \& } \\
\text { Action }\end{array}$ & $\begin{array}{l}\text { MRT Ease of Use, } \\
\text { MRT usefulness }\end{array}$ & $\begin{array}{l}\text { Promotion: Member Get Member, } \\
\text { Advertising: alternative media in office } \\
\text { building, mall, cinema and other public } \\
\text { area } \\
\text { PR: User testimony, photo contest using } \\
\text { MRT }\end{array}$ \\
\hline
\end{tabular}

\section{Conclusion}

PT MRT Jakarta Realize that the project success is depend on the public support and acceptance to the project. The company have already implement the communication strategy as a management function that is planned, implement and evaluate in regular basis (annual). It means, Public Relations Function and communication strategy has already attached with the corporate strategy as a whole. It showed by the communication roadmap that follow the construction period. Means, communications program has considered the company needs in every project phase. 
There is a suggestion to complete the communication roadmap based on project phase:

\section{References}

[1] Belch, George E and Michael A. Belch. (2012). Advertising and Promotion: An Integrated Marketing Communication Perspective International Edition. McGraw-Hill Book Co.

[2] Botan, H.Car.1 \& Vincent Hazleton, (1989). Public Relations Theory. New Jersey: Lawrence Erlbaum Associates, Inc., Publisher. Hal 248.

[3] Effendy, Onong (1999). Hubungan Masyarakat Suatu Studi Komunikologis. Bandung: PT Remaja Rosdakarya, hal. 107

[4] Effendy, Onong (2005).IImu Komunikasi \& Praktek. Bandung: PT Remaja Rosdakarya

[5] Frans, Jeffkins (2003). Public Relations. (Haris Munandar, Penerjemah). Jakarta: Erlangga.

[6] Irawan, Prasetya. (2007). Penelition Kualitatif dan Kuantitatif untuk Ilmu-IImuSosial. Depok: DIA FISIP UI

[7] Iriantara, Yossal. (2004). Dasar-Dasar Humas. Jakarta: Ghalia Indonesia

[8] Kasali, Rhenald. (2008). Riset Kualitatif dalam Public Relations \& Marketing Communications. Jakarta: Penerbit Bentang

[9] Kountur, Ronny. (2003). Metode Penelitian:Untuk Penulisan Skripsi dan Tesis. Jakarta: Peberbit PPM.

[10] Newman, Lawrence. (2003). Social Research Methods: Qualitative and Quantitative Approaches. London: Allyn and Bacon

[11] Ruslan, Rosady. (2003). Metode Penelitian Public Relations dan Komunikasi. Jakarta: Raja Grafindo Persada.

[12] Botan, C. (2006), "Grand strategy, strategy, and tactics in public relations", in Botan, C. and Hazleton, V. (Eds), Public Relations Theory, Lawrence Erlbaum, Mahwah, NJ, pp. 223

[13] Dolphin, R.R. and Fan, Y. (2000), "Is corporate communication a strategic function?", Management Decision, Vol. 38 No. 2, pp. 99-106.

[14] J. Goczol, C. Scoubeau, (2003) "Corporate communication and strategy in the field of projects", Corporate Communications: An International Journal, Vol. 8 Iss: 1, pp.60-66

[15] Wenxiu. Peng (2015). Analysis of New Media Communication Based on Lasswell's "5W" Model. Rome: Journal of Educational and Social Research 